\title{
Biosynthesis of Silver Nanoparticles from a New Bacterial Isolate and Their Effect on Dermatophyte Fungi
}

\author{
Sherif Moussa Husseiny ${ }^{\mathrm{a}}$, Taher A. Salah ${ }^{\mathrm{b}}$, Eman M. El-Sayed ${ }^{\mathrm{b} *}$ \\ ${ }^{a}$ Microbial Biotechnology Lab., Botany Department, Faculty of Women for Art, Science and \\ Education, AinShams University, Cairo, Egypt \\ ${ }^{\mathrm{b}}$ Nanotechnology \& Advanced Materials Central Lab., Agricultural Research Center, El Gamaa \\ St., Giza, Egypt
}

\begin{abstract}
Nanoparticles biosynthesis is a potential method for synthesizing of nanoparticles due to its simplicity and non-toxicity. In the present study, microorganisms were isolated from routh of poultry on nutrient agar medium. Resulted isolates were screenedfor their abilities to synthesize extracellular silver nanoparticles (AgNPs). Isolate producing the smallest AgNPswas identified by sequencing its $16 \mathrm{~S}$ rDNA gene, and the results revealed it to be anew strain of Bacillussp., which was assigned anaccession number of KT982274. Factors affecting the nanoparticle size were optimized achieving the smallest AgNPsparticle size $\sim 4 \mathrm{~nm}$ bya $96 \mathrm{~h}$ culture and incubating mixture of equal volumes of bacterial filtrate and silver nitrate solution, at $40^{\circ} \mathrm{C}$, for $18 \mathrm{~h}$, and $\mathrm{pH}$ of 7. Spherical AgNPs of 4nm were characterized by high resolution transmission electron microscopy (HR-TEM), and Fourier transform infrared spectroscopy (FT-IR) gave bands of proteins at 1442.2 , and $1631.2 \mathrm{~cm}^{-1}$ corresponding to bands of I and II amide, respectively. Antimicrobial effect of the produced AgNPsagainst pathogenic yeast cells showed that the Minimum inhibitory concentration(MIC) after was $132 \mathrm{ppm}$, and $265 \mathrm{ppm}$ for Microsporumaudouinii and Trichophytonviolaceum respectively after $3 \mathrm{~h}$ of exposure. After $6 \mathrm{~h}$, MIC was 8 ppm, 66 ppm, and 33 ppm for Microsporumaudouinii, Trichophytonviolaceum, and Candida albicans, respectively.
\end{abstract}

Keywords: Biosynthesis. Nanoparticles. Molecular identification. MIC. Antifungal

*Corresponding author: Eman Mohammed El-Sayed

e-mail: emmymicrobiologist@yahoo.com 


\section{Introduction}

Nanotechnology field is important field due to its potential applications in medicine and other science fields. This field is growing very rapidly with various interesting applications in biosensing, drug delivery and cancer therapy(Ranjaniet al., 2016).Nanoparticles (NPs)haveimproved new properties, such as morphology,and size of the particles.(Kaviyaet al., 2011). Physical methods have high expense and low yields (Li et al., 1999), and chemical methods require capping agents for size stabilization of the nanoparticles, toxic solvents cause contamination to the environment(Wang et al., 2007), whereasbiosynthesis method is cheaper, more safe method, and producing large quantities of nanoparticles (Narayananand Sakthivel, 2010; Ramezaniet al., 2010).

Biosynthesis of nanoparticles,includesthe use of plant, bacteria, fungal, and algae. Bacteria have received the most attention in this area, due to itsgenetic manipulation without much difficulty and ease of handling (Klaus et al., 2001). Fungi can also secrete large amounts of enzymes;which play important roles in nanoparticles synthesis(Mandal et al., 2006). Theuseof plants for synthesis of nanoparticles can eliminate the difficultof removing cell cultures (Shankar et al. 2004), and it can be easy for scaling up for huge synthesized amounts of NPs (Songand Kim, 2009). Moreover, nanoparticle can be produced either intracellular and extracellular, based on the utilized microorganism (Ahmad et al., 2003). Extracellular synthesis ofNPs has the advantage of easy downstream processing.

One of the most widely used nanomaterial is silver nanoparticles (AgNPs) (Vaidyanathanet al., 2010).AgNPs have found tremendous applications in the field of diagnosis, therapeutics and antimicrobials, sensors, and micro-electronics(Klaineet al., 2008).

AgNPs have an antimicrobial effect due to producing reactive oxygen species which damage the organelles inside pathogenic cells and can also damage cell membrane.

So keeping in view the advantage of AgNPs synthesized from microorganisms, this study was based on the synthesis of AgNPs from many isolated strains from the soil and routh of poultry and checking their antimicrobialeffect against pathogenic fungal strains. 


\section{Materials and methods}

\subsection{Isolation microorganisms}

The microorganism used was isolated from garden soil and purified on nutrient agar, which consists of; $5 \mathrm{gm}$ peptone, $3 \mathrm{gm}$ beef extract, $15 \mathrm{gm}$ agar into $1 \mathrm{~L}$ distilled water, $\mathrm{pH} 6.8$ at $25^{\circ} \mathrm{C}$ (Lechevalierand Solotorovsky, 1961).

\subsection{Screening of isolates for ability to biosynthesis silver nanoparticles (NPs)}

Each fungus was grown in 250 Erlenmeyer flasks containing $100 \mathrm{ml}$ potato dextrose broth at $37^{\circ} \mathrm{C}$ and $120 \mathrm{rpm}$ for $24 \mathrm{hr}$. After incubation, mycelia biomass was separated by filtration by Whatman filter paper No.1. It washed with sterile distilled water several times to remove the traces of media components. Approximately $10 \mathrm{gm}$ of the fungus was resuspended in $100 \mathrm{ml}$

distilled water and $2 \mathrm{mmol} \mathrm{L}^{-1}$ of $\mathrm{Ag}$. Then was incubated at $37^{\circ} \mathrm{C}$ till color changed for dark brown (Sastryet al., 2003).

Bacterial isolates were cultured on nutrient broth medium, growth was allowed for $24 \mathrm{hrs}$. After incubation time, the cultures were centrifuged at $12000 \mathrm{rpm}$ for $10 \mathrm{~min}$. and their supernatants (Minaeianet al., 2008) were used separately for further experiments.

$5 \mathrm{ml}$ of silver nitrate at concentration of $10^{-2} \mathrm{M}$ was added to the reaction vessels containing $5 \mathrm{ml}$ of different supernatants (Minaeianet al., 2008) and incubated for $24 \mathrm{hr}$.

Actinobacteria isolates survey was done as bacteria (Deepaet al., 2013).

Control broth media were prepared without $\mathrm{AgNO}_{3}$.

\subsection{Molecular identification}

It was carriedoutfor the isolate which biosynthesized the smallest particle size, using $16 \mathrm{~S}$ rDNA sequence-based methodat Sigma lab by protocol of GeneJet genomic DNA purification Kit (Thermo). All genomic DNA was isolated from thebacterial isolate. Then, the DNA was used as a template for PCR processes,and F: - AGA GTT TGA TCC TGG CTC AG and R: - GGT TAC CTT GTT ACG ACT T used as primers.The PCR processes was performed in a total 
volume of $50 \mu \mathrm{L}, 20 u \mu$ of each primer, $5 \mu \mathrm{l}$ of the template DNA,and $18 \mu \mathrm{l}$ of water, nucleasefree. The PCR was performed for 35 cycles in a Maxima® Hot Start PCR Master with the initial denaturation at $95^{\circ} \mathrm{C}$ for $10 \mathrm{~min}$, cyclic denaturation at $94^{\circ} \mathrm{C}$ for $30 \mathrm{~s}$, annealing at $65^{\circ} \mathrm{C}$ for 1 min,extension at $72^{\circ} \mathrm{C}$ for $1 \mathrm{~min}$ and $30 \mathrm{~s}$, and final extension at $72^{\circ} \mathrm{C}$ of $10 \mathrm{~min}$. Then, agarose gel electrophoresis was used for analyzingthe reaction products. The product was then purifiedusing the GeneJET ${ }^{\mathrm{TM}}$ purification column. After that, the ABI 3730xl DNA sequencer on GATC Company were used to sequence the PCR product, using the forward and reverse primers. This sequence was then used for BLAST analysis(https://www.ncbi.nlm.nih.gov/nucleotide/). The $16 \mathrm{~S}$ rDNA sequence of the isolated bacteria was also used for phylogenetic analysis using Blast program (Prasadand Turner, 2011).

\subsection{Parameters affecting size of biosynthesized AgNPs}

Different factors were allowed to obtain the smallest AgNPs. Bacillus sp.(KT982274) incubated for6h, 12h, 24h, 48h, 72h, 96h, and 120h, filtrate ratio of $\mathrm{AgNO}_{3}$ to bacterial filtrate: $1: 1,1: 2,1: 3$, and 1:4, incubation temperature at $30^{\circ} \mathrm{C}, 35^{\circ} \mathrm{C}, 40^{\circ} \mathrm{C}$, and $50^{\circ} \mathrm{C}$, reaction incubation time for $6 \mathrm{~h}, 12 \mathrm{~h}, 18 \mathrm{~h}, 24 \mathrm{~h}, 30 \mathrm{~h}, 48 \mathrm{~h}, 72 \mathrm{~h}$, and $96 \mathrm{~h}$, and $\mathrm{pH} \mathrm{6,} \mathrm{7,} \mathrm{8,} \mathrm{9,} \mathrm{and} 10$.

\subsection{Characterization of biosynthesized AgNPs}

Synthesis of silver nanoparticles was tested using UV-Vis spectra at a range $200-800 \mathrm{~nm}$ at a resolution of $1 \mathrm{~nm}$ (Vahabiet al., 2011). The Size of AgNPswasmeasured by laser diffractometer using Zeta Sizernano-series (Nano ZS), and AgNPs was imagedusing transmission electron microscopy (TEM)(Sastryet al., 2003). Presence of AgNPs in the solution was proven by energy dispersive x-ray (EDAX)(Jegaddeset al., 2012). Fourier transform infrared spectroscopy (FT-IR) spectra were recorded in the range $500-4000 \mathrm{~cm}-1$, and crystalline nature(Vahabiet al., 2011), composition and purity of AgNPs was confirmed by X-ray diffraction spectrum (XRD)(Vanajaet al., 2013).

\subsection{Biological activity}

\subsubsection{Minimum inhibitory concentration (MIC)}


It was carried out according to (Watts et al., 2008).After $3 \mathrm{hr}$ and $6 \mathrm{hr}$,MIC was studied for AgNPsatMicrosporumaudouinii, Trichophytonviolaceum, and Candida albicans.

\subsubsection{Microscopic examination TEM of bactericidal cells at sub lethal dose}

HR-TEM images were taken before and after treating the microbial strains with AgNPs to show the bactericidal effect by morphological changes of the cells.

\section{Results}

\subsection{Molecularidentification of the selected isolated bacteria}

Molecular characterization of the isolated bacteria was carried out using 16S rRNA fragment (Singhet al, 2012).

The PCR products were analyzed using electrophoresis on $1.5 \%$ agarose gels and stained with ethidium bromide. Thenthe DNA bands were visualized and documented using a gel documentation system (Sarkaret al., 2012).

The PCR amplified products were sequencedat Sigma Labs.Identification of the species and similarity calculations were performed. The sequences of approximately 1500 baseswere comparedwith sequences available in GenBank, using BLAST network services. Phylogenetic relationship was outlined and found similarity index, distance between the isolate and maximum likelihood pattern analysis (Sarkaret al., 2012).

\subsection{Phylogenetic analysis of strain ICI 54399(Bacillus sp.(KT982274))based on 16S rDNA sequence}

The resulting sequences were aligned and compared with those stored in GenBank by using BLAST alignment software (NCBI) and phylogenetic tree was drawn (Tripathiet al., 2013 28) as shown in (Fig. 1).

The 16S rRNA ribosomal PCR amplified product size was $1655 \mathrm{bp}$. The $16 \mathrm{~S}$ rRNA gene sequences showed $98 \%$ similarity with Bacillus sp. in the existing GenBank database (Singh et al., 2012). 


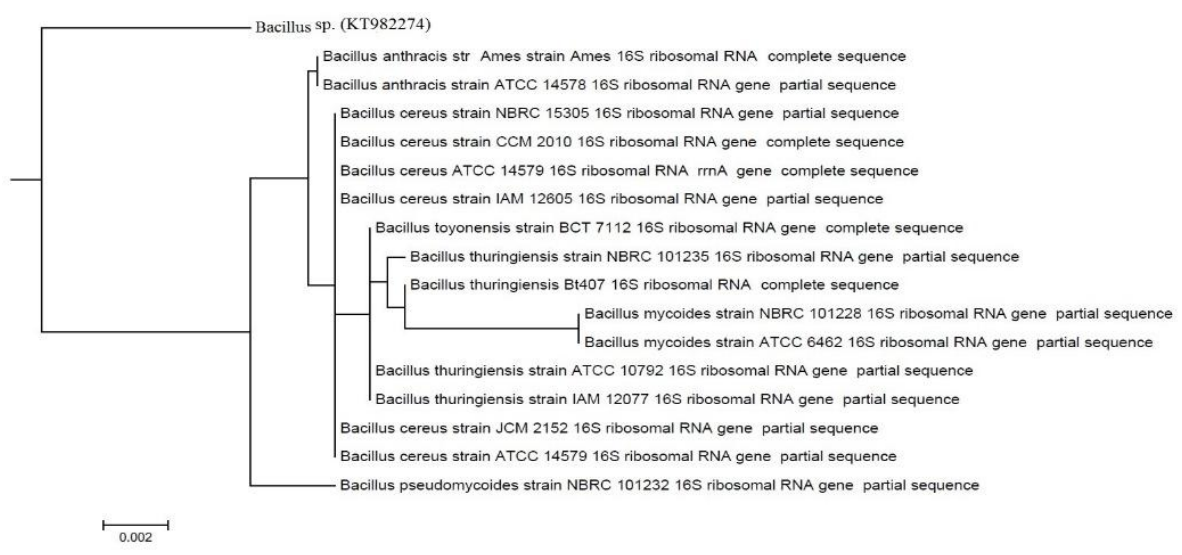

Fig.1 Phylogenetic analysis of different 16S rRNA sequences of Bacillus sp., collected from NCBI-GenBank.

\subsection{Optimization of synthesized AgNPs}

Changing the color of the filtrate into dark brown indicates the formation of AgNPs and this proved that the isolated bacterium(Bacillus sp.(KT982274))could produce AgNPs.Some parameters affected on this isolate let it produce small sized AgNPs, which are more effective as antimicrobial agent. Those parameters shown below.

\subsubsection{Effect of bacterial age}

As bacterial incubation time increased, the NPs size decreased until reached $46.26 \mathrm{~nm}$ after 96 hr (Fig. 2a).

\subsubsection{Effect of silver concentration to bacterial filtrate ratio; (V/V)}

Fig.2b shows decreased particle size to $43.26 \mathrm{~nm}$ at $1: 1$ ratio of bacterial filtrate to $\mathrm{Ag}^{+}$.

\subsubsection{Effect of temperature of the reaction}

Increasing temperature until $40^{\circ} \mathrm{C}$ lead to decreasing of NPs size to $38.79 \mathrm{~nm}$ (Fig. 2c).

\subsubsection{Effect of incubation time}

It was interpreted that the size of NP formation decreases as the incubation time increases till 18hr (Fig. 2d).

\subsubsection{Effect of $\mathrm{pH}$}

The smallest particle size $(4 \mathrm{~nm})$ was documented at a pH 7 (Fig. 2e. 
a)

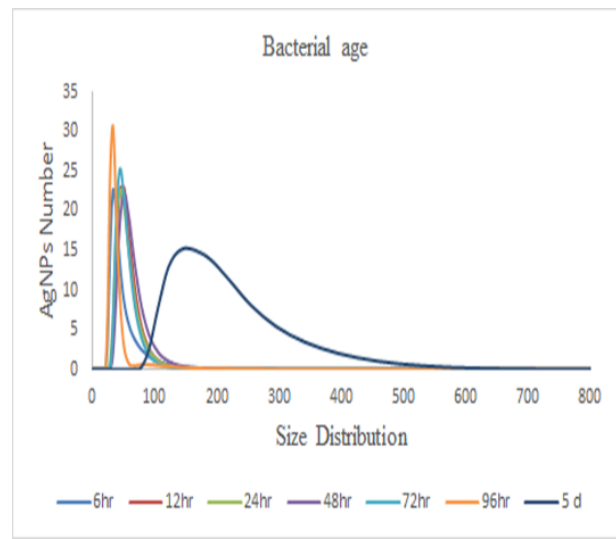

c) b)

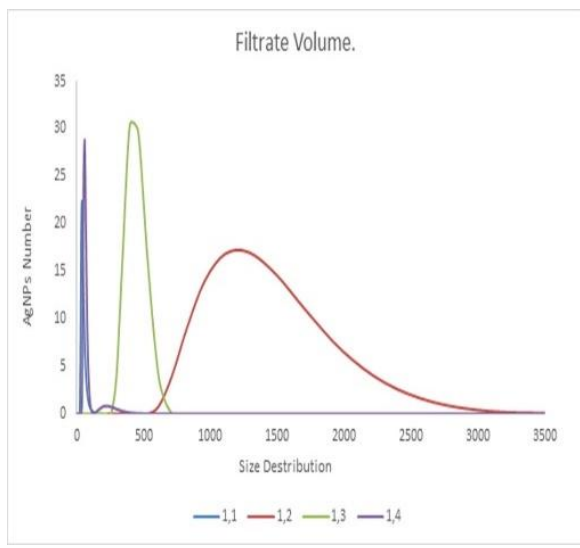

d)
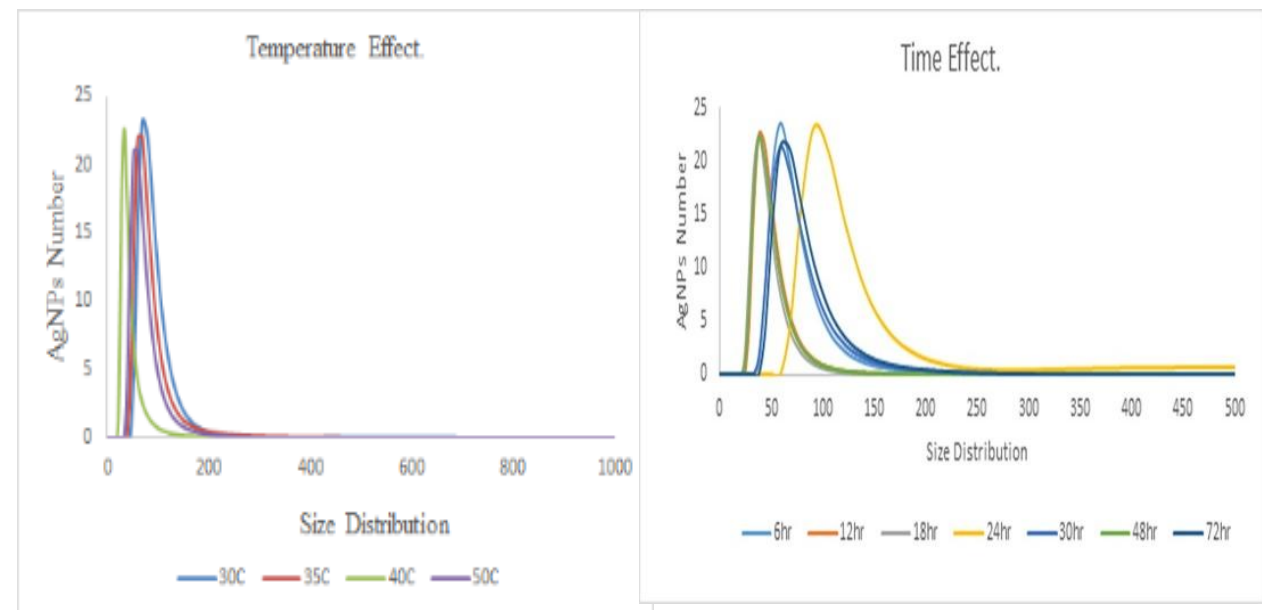

e)

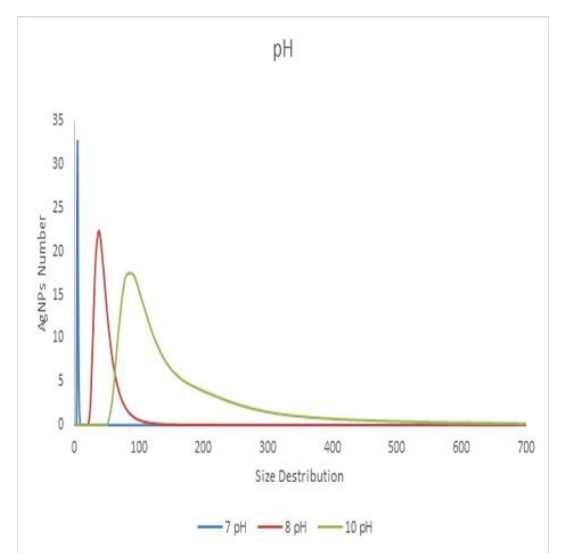

Fig.2 Parameters affecting biosynthesized AgNPs. a bacterial age, b filtrate ratio, c Temperature, dtime, and e $\mathrm{pH}$. 


\subsection{Characterization of biosynthesized AgNPs}

\subsubsection{UV-visible spectroscopy}

Reaction solution was given by periodic sampling of the reaction mixture at different time: $6,12,18,24$ and $30 \mathrm{~h}$ by using UV-visible spectroscopy (Fig. 3a). The spectra clearly showed increase in intensity of silver solution with time, indicating the formation of increased number of AgNPs in the solution.

\subsubsection{Zeta sizernano}

Particle size and size distribution of AgNPswas carried outby zeta sizer, and the results showed that AgNPs size was $4 \mathrm{~nm}$ (Fig. 3b).

\subsubsection{High resolution transmission electron microscopy (HR-TEM)}

Size and morphology of synthesized AgNPswere determined by HR-TEM.TEM image shows well-dispersed AgNPs with an average particle size of $4 \mathrm{~nm}$ and few particles with higher size distribution (Fig. 3c).

\subsubsection{Fourier transform infrared spectroscopy (FT-IR)}

It wasperformedin order to identify the proteins which are responsible for the reduction of $\mathrm{Ag}^{+}$ions to AgNPsin the bacterial filtrate. Absorbance bands seen at 1442.2, 1631.2, and 3458.6

$\mathrm{cm}^{-1}$ were assigned to $\mathrm{CH}$ bending vibrations of $\mathrm{CH}_{3}$ group, $\mathrm{C}=\mathrm{C}$ Stretching vibrations of nonconjugated group, and $\mathrm{NH}$ stretching vibrations of free NH group, respectively (Fig. 3d).

\subsubsection{Energy dispersive x-ray (EDAX)}

AgNpswere proven to be found in the solution as shown in Fig. 3e.

\subsubsection{X-ray diffraction spectrum (XRD)}

AgNPs composition and purity were confirmed using (XRD), as shown in Fig. 3f.Fraction peaks shown at $38.4^{\circ}, 44.7^{\circ}, 64.1^{\circ}$ and $77.1^{\circ}$ corresponding lattice plane value was indexed at (111), (200), (220) and (311) planes of face centered cubic (FCC). These peaks are in good agreement with reference of FCC structure from joint committee of powder diffraction standard (JCPDS) Card No-087-0720. 
a)

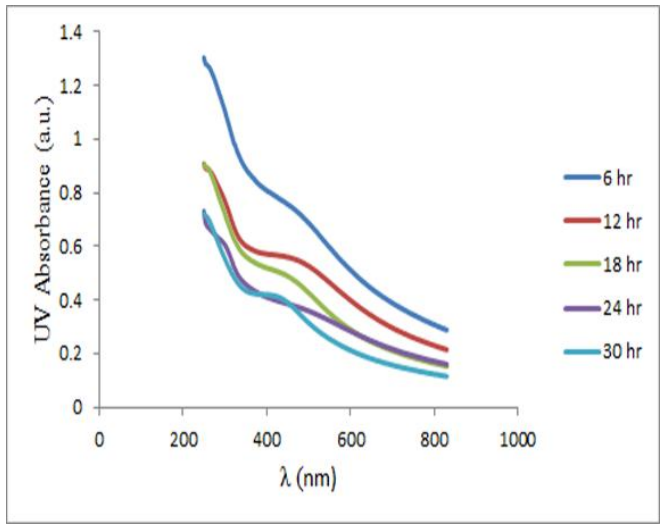

c)

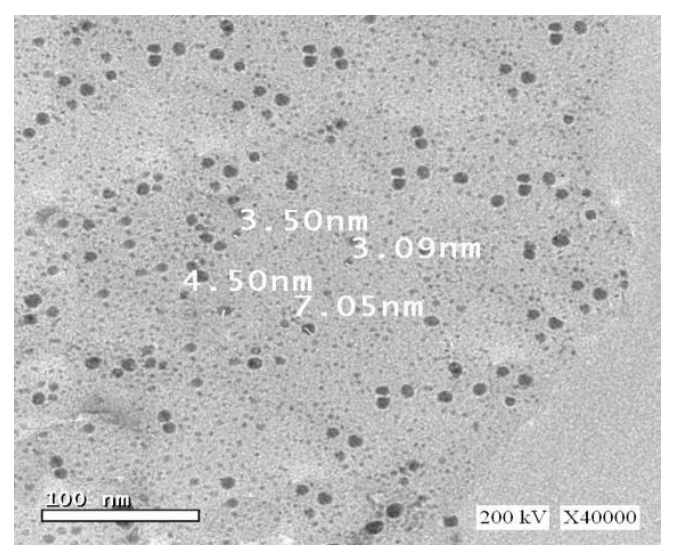

e)

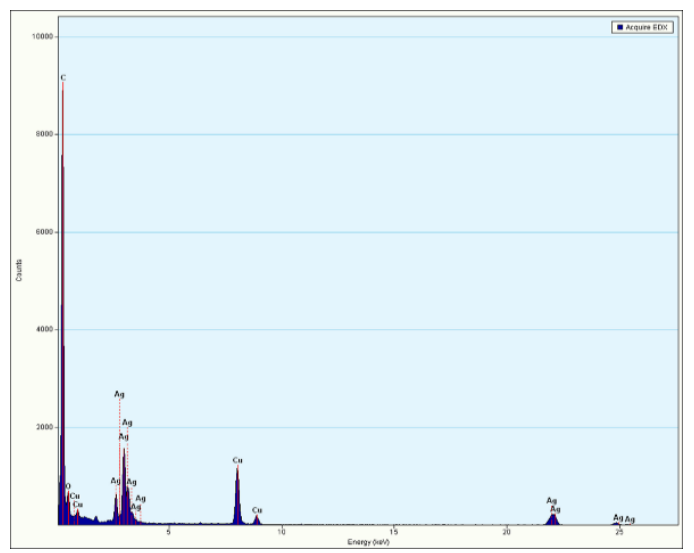

b)

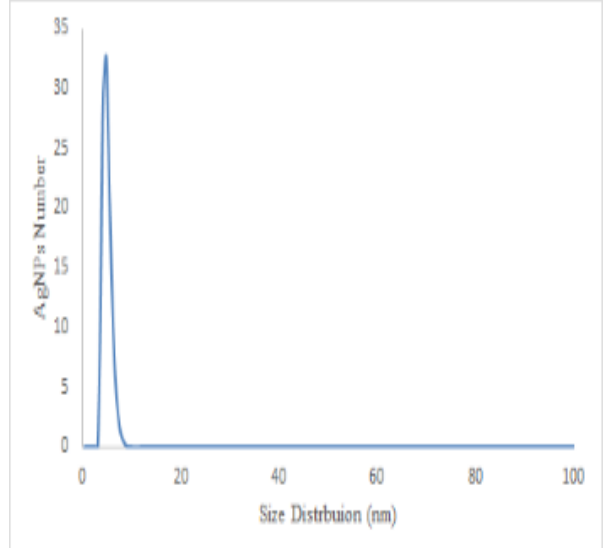

d)

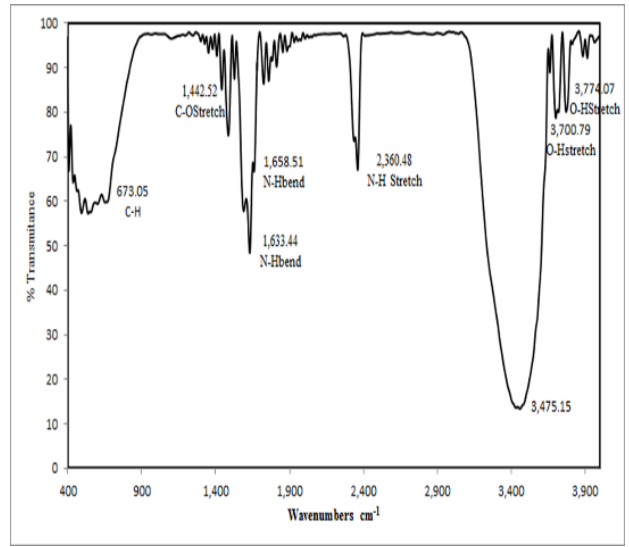

f)

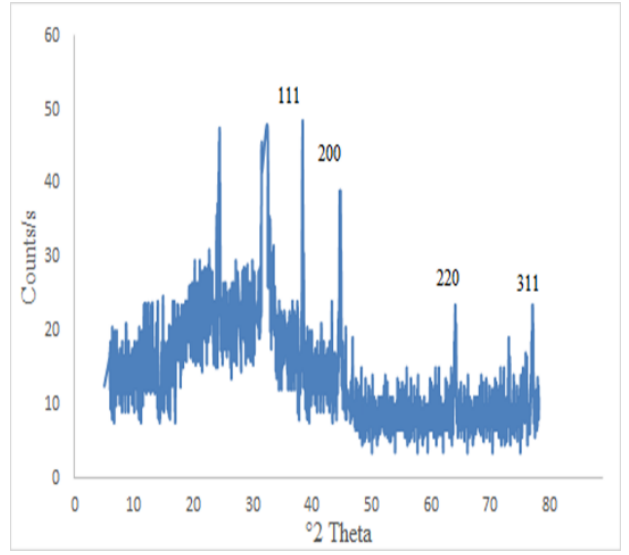

Fig.3 Characterization of optimized AgNPs.aUv-visible spectroscopy,b Zeta sizer,cTEM image,d FT-IR spectrum,eEDAX, and $\mathbf{f}$ XRD. 


\subsection{Minimum inhibitory concentration (MIC)}

MIC results of the dermatophyte strains shown in Table 1.

Table 1 MIC for M. audouinii, T. violaceum, and C.albicans

\begin{tabular}{ccc}
\hline Affected fungi & $3 \mathrm{hr}$ & $6 \mathrm{hr}$ \\
\hline $\begin{array}{c}\text { M.audouinii } \\
\text { Conc. of NPs (ppm) }\end{array}$ & 132 & 8 \\
$\begin{array}{c}\text { T.violaceum } \\
\text { Conc. of NPs (ppm) } \\
\begin{array}{c}\text { C.albicans } \\
\text { Conc. of NPs (ppm) }\end{array}\end{array}$ & 265 & 66 \\
\hline
\end{tabular}

\subsection{HR-TEM imaging before and after treatment with AgNPs}

Comparison ofTEM micrographs of thin sections of fungal myceliabefore and after reaction with $\mathrm{Ag}^{+}$showed that $\mathrm{Ag}^{+}$was accumulated in the form of scattered particles inside cells and also some particles bound to the cell wall.Also, aggregation of granules in the cytoplasm occurred. Thickness of the cell wall was noted before cell wall rupture.Granules inside the cells are more affected after $6 \mathrm{hr}$ (Fig. 4,5,6)(Reynolds and E.S., 1963), and (Karnovsky, and M.J., 1965). 
a)

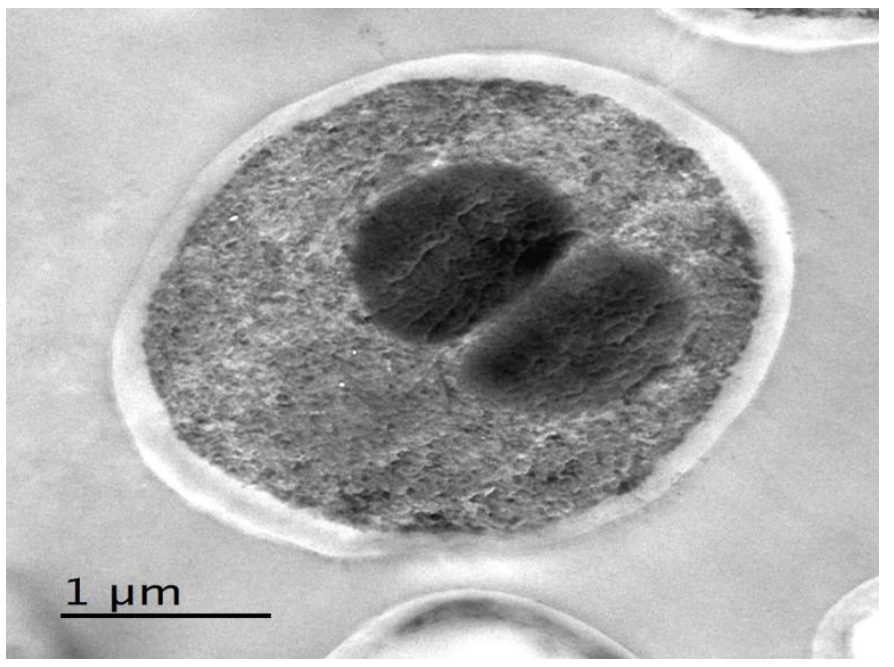

b)

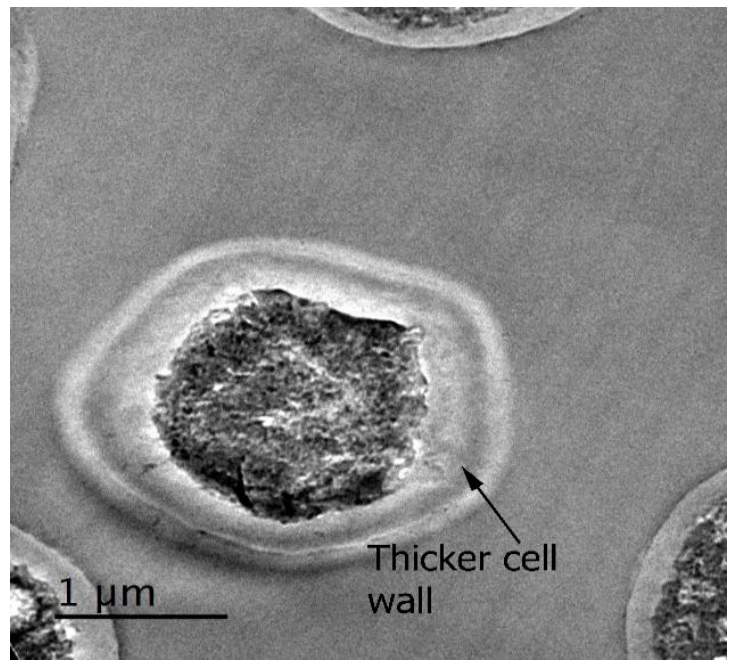

c)

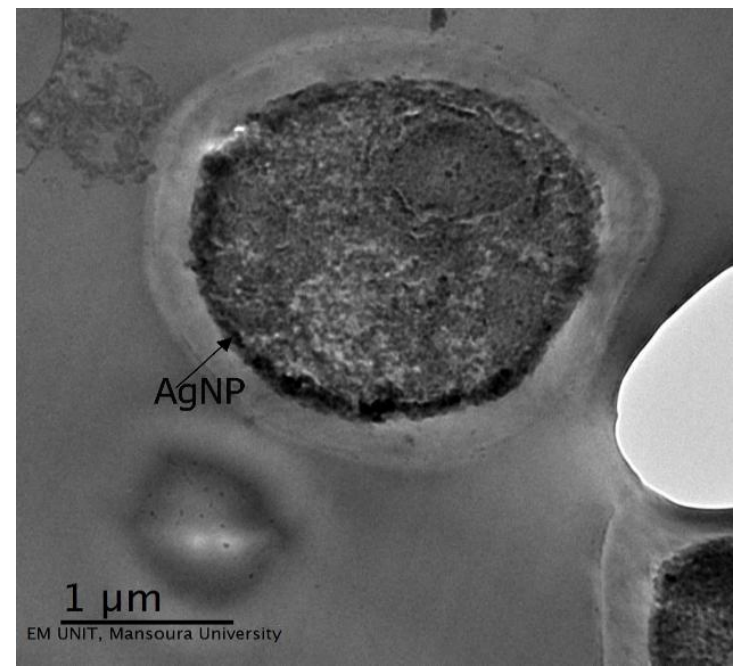

Fig.4 TEM micrographs.athin sections of Candida albicans,b, c cells after reaction with $\mathrm{Ag}^{+}$ ions(cell dosage: $33 \mathrm{ppm}$; temperature: $28^{\circ} \mathrm{C}$; contact time: $6 \mathrm{hr}$ ) showing accumulation of AgNPs inside the cell. 
a)

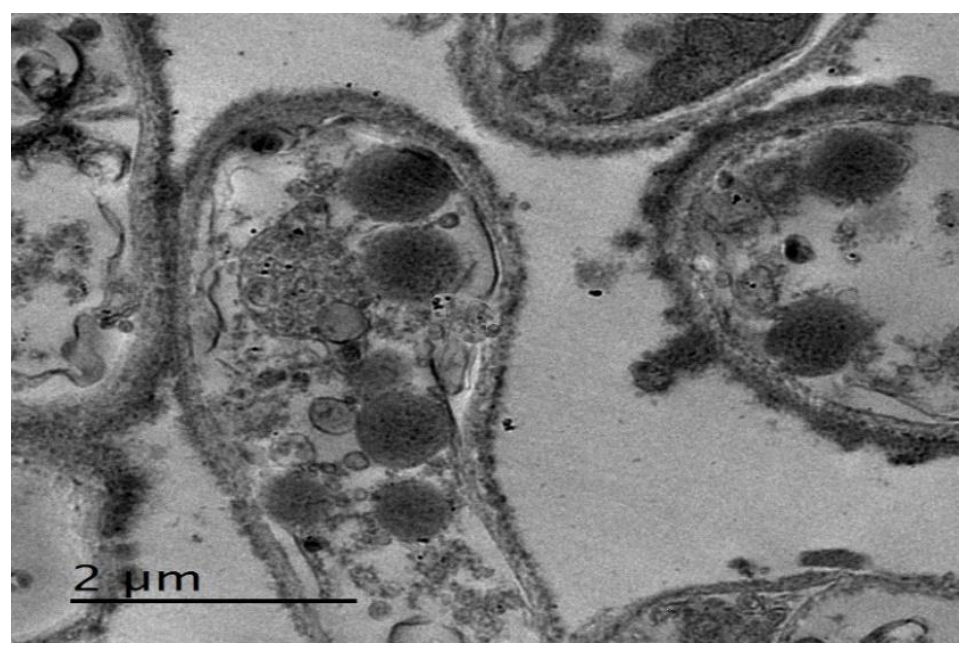

b)

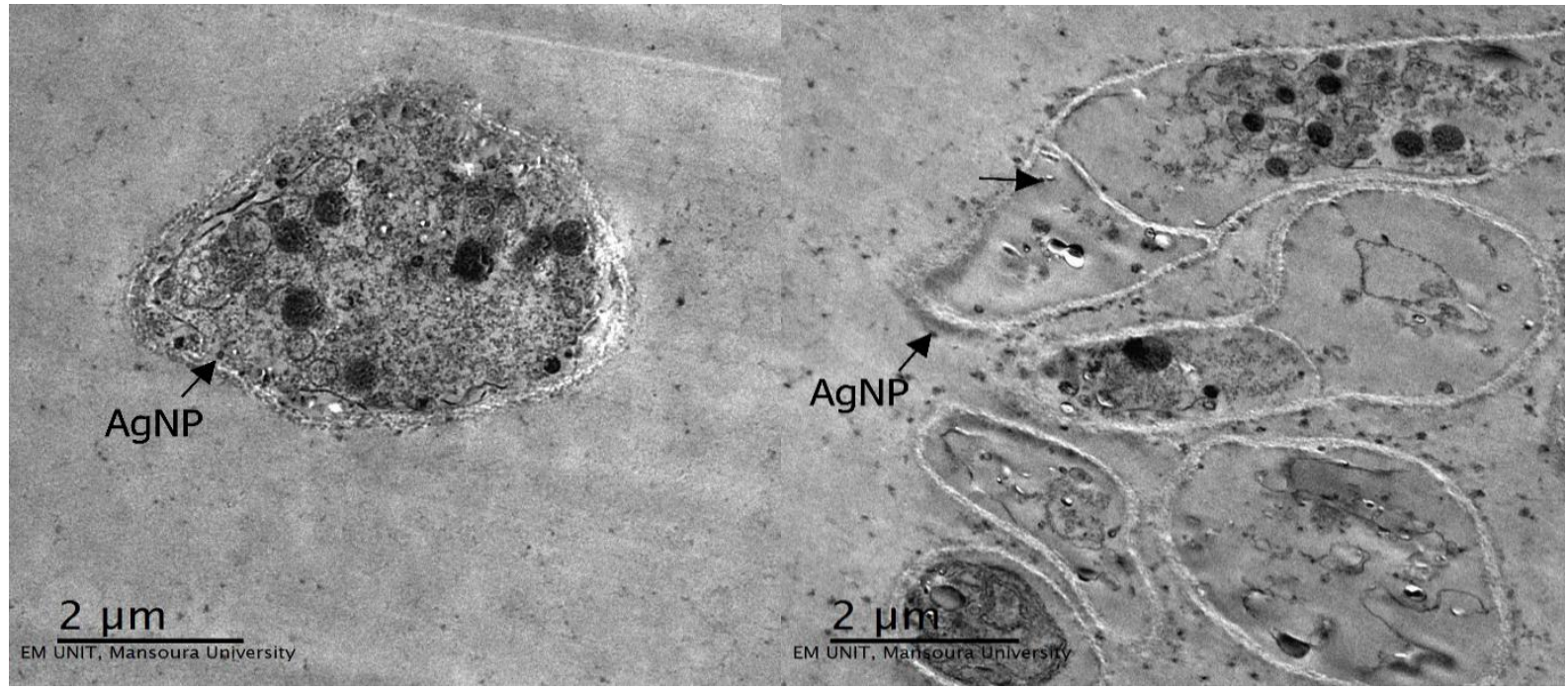


c)

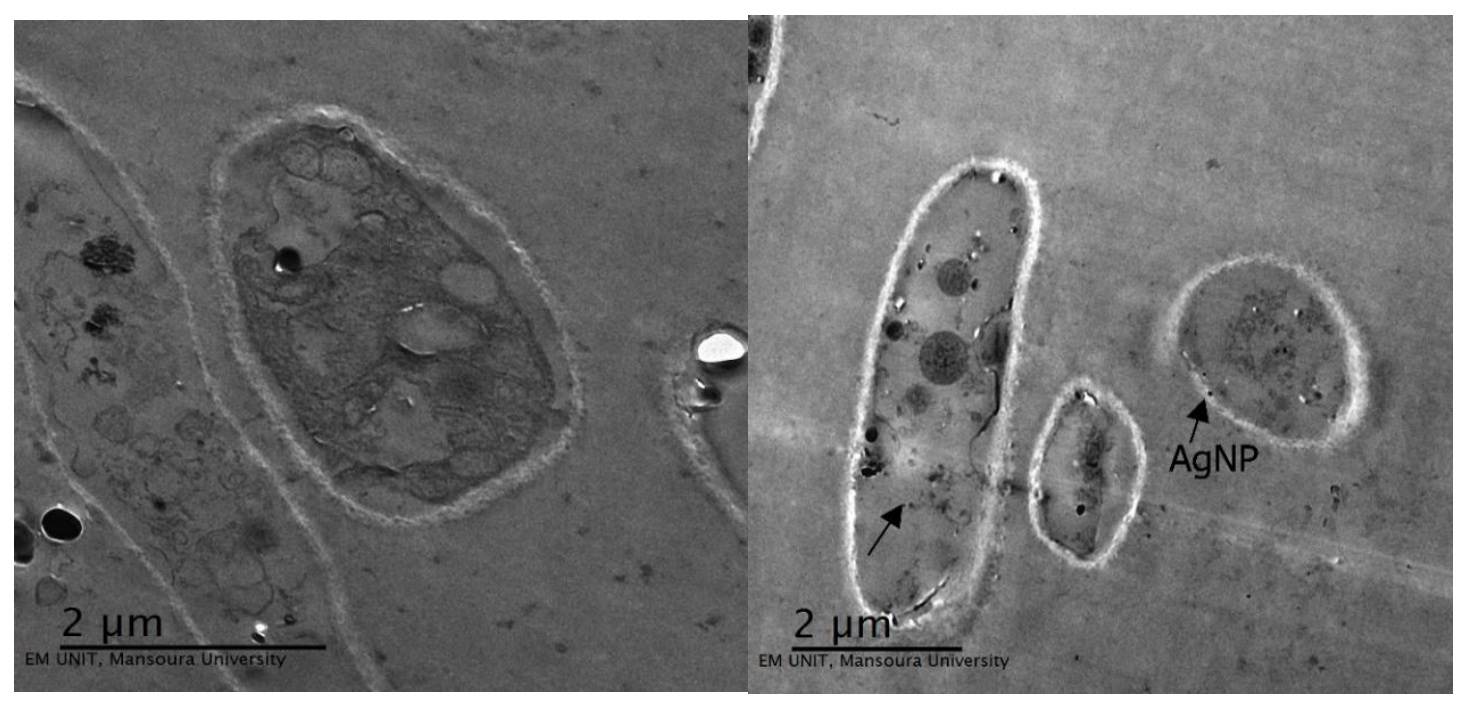

Fig.5 TEM micrographs recorded from athin sections of T.violaceum cells, $\mathbf{b}$ after reaction with $\mathrm{Ag}^{+}$ions(cell dosage: $265 \mathrm{ppm}$; temperature: $28^{\circ} \mathrm{C}$; contact time: $3 \mathrm{hr}$ ), and c (cell dosage: 66 ppm; temperature: $28^{\circ} \mathrm{C}$; contact time: $6 \mathrm{hr}$ ) showing accumulation of AgNPs, arrows indicate that particles accumlated in cells and on its wall.

a)

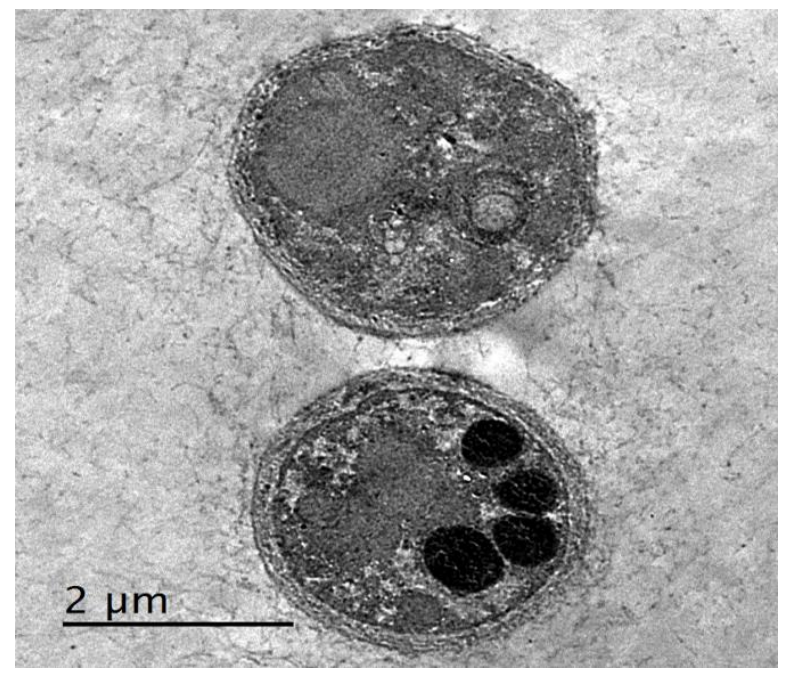


b)

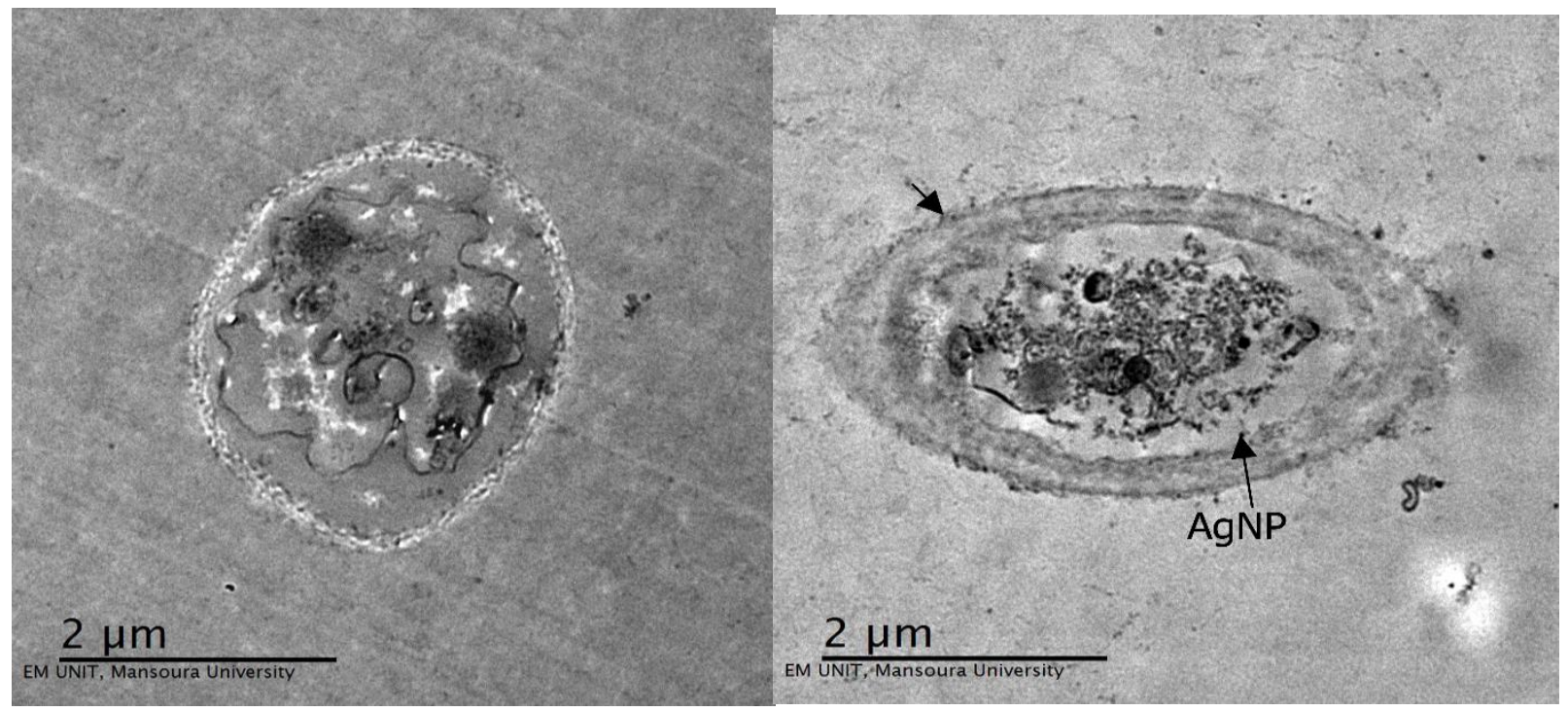

c)

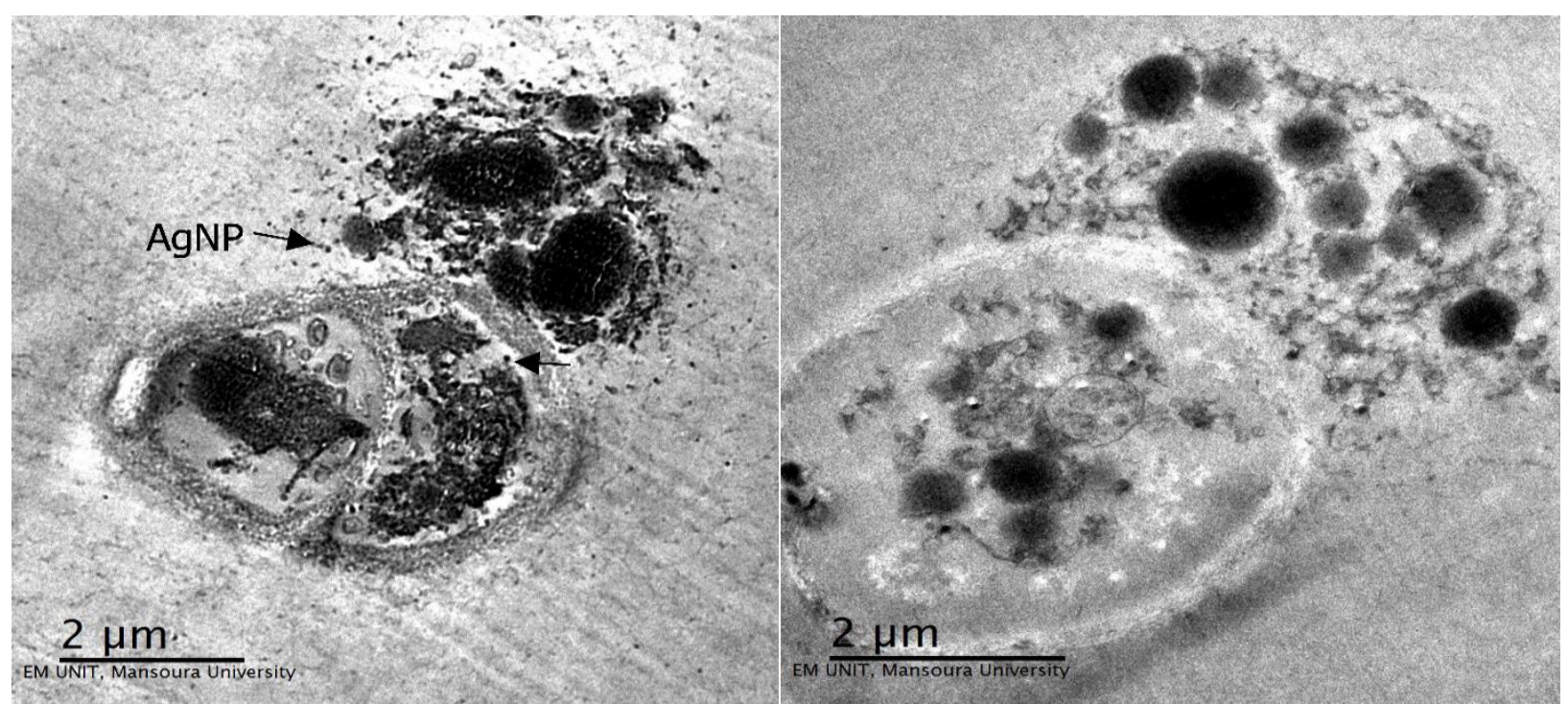

Fig.6 TEM micrographs recorded at different magnifications. aThin sections of M.audouinii

cells, bafter reaction with $\mathrm{Ag}^{+}$ions (cell dosage: $132 \mathrm{ppm}$; temperature: $28^{\circ} \mathrm{C}$; contact time: $3 \mathrm{hr}$ ), and c (cell dosage: $8 \mathrm{ppm}$; temperature: $28^{\circ} \mathrm{C}$; contact time: $6 \mathrm{hr}$ ) showing accumulation of silver nanoparticles, arrows indicate that particles accumlated on cells and on its wall. 


\section{Discussion}

The aim of this study was to biosynthesize small nanoparticles, using egyptian isolates, and disinfect dermatophyte fungi by these AgNPs.

AgNPs showed to be more effective when applied to culture supernatant than if applied to the bacterial cells, this is may be due to extracellular secretion of the enzyme in the medium, extracellular synthesis of AgNPs may occur when the microorganism secretes the reducing enzymes out in the media, so the $\mathrm{Ag}^{+}$are reduced to $\mathrm{Ag}$ nuclei which subsequently grow by further reduction of $\mathrm{Ag}^{+}$and accumulate on these nuclei (Ramanathanet al., 2010). This agrees with Minaeianet al.,2008, who showed the bacterial solution of Bacillussubtilis after incubation for $24 \mathrm{hr}$ at $37^{\circ} \mathrm{C}$ with $\mathrm{AgNO}_{3}$ solution turned brown after $24 \mathrm{hr}$.

The selected bacterial isolate from all isolated microorganisms and some parameters were done to minimize the AgNPs.

At an age of the bacteria after $96 \mathrm{hrAgNPs}$, size was $46.26 \mathrm{~nm}$, which was smaller than AgNPs size after longer time; this might be due to the completion of NPs formation in the solution or the unavailability of $\mathrm{AgNO}_{3}$ for further reaction. The sameresults was showed byKadukováet al., 2014, who stated that between $10^{\text {th }}$ and $14^{\text {th }}$ day of alga Parachlorellakessleri small $\mathrm{Ag}^{+}$ions were synthesized but after the $15^{\text {th }}$ day, the AgNPs wereaggregated and precipitated.

Equal volume ratio of bacterial filtrate to $\mathrm{AgNO}_{3}$ caused production of small $\mathrm{AgNPs}$ than other ratios, whereas Christopheret al.,2015 found that the maximum AgNPssynthesis occurred in 2:1 ratio. This may be because that at higher ratios of bacterial filtrate to $\mathrm{AgNO}_{3}$, the amount of the $\mathrm{AgNO}_{3}$ is fully reduced by the same amount of bacterial filtrate and the increased amount of bacterial filtrate still in the solution.

Reaction temperature at $40^{\circ} \mathrm{C}$ caused producing AgNPs of smaller size.Sundaramet al.,2012 found that when the reaction temperature is higher than $50^{\circ} \mathrm{C}$, there is no observable formation of NPs within a time period of $24 \mathrm{~h}$; this may be because of the degradation or inactivation of the biomolecules which are responsible for the reduction of silver metal. 
Incubation time is an important factor, as after $18 \mathrm{hr}$ of incubation the AgNPs were at small size. Sawareet al., 2014 whose study interpreted that agglomeration was observed at higher temperature within $48 \mathrm{~h}$. Also, Vanajaet al.,2013 discovered that agglomeration of NPs shows the larger size of NPs. So the optimum time duration for the formation of NPs was $1 \mathrm{~h}$.

The results showed that AgNPswere with size of $4 \mathrm{~nm}$ at $7 \mathrm{pH}$.Veerasamyet al., 2011 noticed that at acidic condition the formation of AgNPswas suppressed; so large AgNPs were formed at lower $\mathrm{pH}$.Lower $\mathrm{pH}$ might have caused agglomeration of AgNPsdue to the over nucleation and formation of larger NPs. In the alkaline conditions, more precipitation or agglomeration occurred may be due to the instability of AgNPs or due to lack of stabilizing agent.

TEM micrograph showed spherical AgNPs with size 3-4 nm. Adelet al.,2013 showed TEM images at the range 9.96-22.7 nm of AgNPs using Bacillussp.

In our study, EDAX characterization for AgNPs agrees with Waranet al., 2012 that showed a strong peak at $3 \mathrm{keV}$ indicated the presence of AgNPs using Padinatetrastromatica extract.

The FT-IR spectra of biosynthesized AgNPs showed bands noted that proteins was the suspected compound which was detected in the filtrate after adding the bacterial filtrate. Amino acids and peptides acted as reduction and stabilizing agents that prevent agglomeration by covering the AgNPs. Also, the results detected that the capping agents of the AgNPs may be an aromatic compounds or amines or alkanes (Waranet al.,2012).

AgNPscan be used as antimicrobial agent and this is relatively new, and has attracted significant attention in recent years (Moroneset al., 2005).Selective toxicity of the ideal antimicrobial drug is an important feature; so the drug is harmful only to the parasite but be harmless to the host.

NPs have many ways to enter the cell. This may be by diffusing through cell membranes as well as through adhesion, endocytosis,membrane potential or disruption of membranes, genotoxicity, oxidation of proteins, formation of reactive oxygen species (ROS), interruption of energy transduction, and releasing of toxic constituents. AgNPs adhered to the surface alter the membrane properties, therefore affecting the permeability and the respiration of the cell; they can penetrate inside bacteria leading todamage of DNA, and releasing ofthe toxic $\mathrm{Ag}^{-}$ions. 
Degradation of lipopolysaccharide molecules, forming pits in the membrane, and changes in membrane permeability due to AgNPshave also been reported (SondiandSalopek-Sondi, 2004).

From the reported results the synthesized AgNPs exhibited a highly pronounced antifungal activity against the tested yeast which might be probably through destruction of yeasts potential and membrane integrity resulting in the formation of pores and then cell death. Several other studies suggest that, inhibition of bud growth correlates with membrane damage and suggest that AgNPs inhibit the normal budding process through destruction of the membrane (Nasrollahiet al., 2011).

In this study, AgNPs showed antifungal effect against Candida albicans, Trichophytonviolaceum, and Microsporumaudouinii.

Lethal dose of C.albicans after $6 \mathrm{hr}$ was $33 \mathrm{ppm}$, for T.violaceum after $3 \mathrm{hr}$ was $265 \mathrm{ppm}$, and after $6 \mathrm{hr}$ was $66 \mathrm{ppm}$, and MIC for M. audouinii after $3 \mathrm{hr}$ was $132 \mathrm{ppm}$ and $8 \mathrm{ppm}$ after 6 hr.

That agrees with Nasrollahiet al., 2011 whose study proved the effectiveness of AgNPs against Candida albicans (ATCC 5027).

Kim et al., 2008reported that nano-Ag, in an IC80 range of 1-7 ppm, showed significant antifungal activity against Trichophytonmentagrophytes and Candida species.

TEM images before adding AgNPs to those cells differ from images after AgNPs adding. Lethal effect of AgNPs may be due to their bounding on microbial cells and thus damaged the cell wall and then accumulated inside the cell and on the cell wall, so damaged the organelles and devaculated the vacuoles. The cytoplasm showed aggregation. Cell wall might have become thicker to defense on the cell from rupture, and at least the cell wall was ruptured and also the organelles.

\section{Conclusion}

AgNPs in the size of $\sim 4 \mathrm{~nm}$ are synthesized by the supernatant of a new isolated bacteria BacillusKT982274 when $\mathrm{AgNO}_{3}$ is added to it.

The AgNPs synthesized exhibited remarkable antifungal activity against Microsporumaudouinii, Tricoptytonviolaceum, and Candidaalbicans. 
Fungicidal activity of AgNPs has proved their fungicidal effect at such low concentrations (ppm), which do not reveal acute toxic effects on human cells, in addition to their low cost, and overcoming resistance when compared to conventional antibiotics.

\section{References}

Adel,M. M.; Amin,M.; El Batal,A. I. and Ali, A. E. E.,Studies on Bacterial Synthesis of Silver Nanoparticles Using Gamma Radiation and Their Activity against Some Pathogenic Microbes, 91-92,(2013).

Ahmad,A.;Mukherjee, P.;Senapati, S.; Mandal, D.; Islam, M. Kh.; Kumar, R. and Sastry, M.,Extracellular biosynthesis of silver nanoparticles using the fungus Fusariumoxysporum, Colloids Surfaces, B: Biointerfaces, 27, 313-318, (2003).

Christopher,J. G.; Saswati,B. and EzilraniP., Optimization of Parameters for Biosynthesis of Silver Nanoparticles Using Leaf Extract of Aegle marmelos,Brazilian Archives of Biology and Technology, 5, 702-710, (2015).

Deepa, S.; Kanimozhi, K. and Panneerselvam, A., (2013), Antimicrobial activity of extracellularly synthesized silver nanoparticles from marine derived actinomycetes, Int. J. $\begin{array}{lllll}\text { Curr. } & \text { Microbiol. } & \text { App. } & \text { Sci., } & 2(9\end{array}$ ), 223-230.

Kaduková,J.;Velgosová,O.;Mražíková,A. and Marcinčáková, R.,The effect of culture age and initial Silver concentration on biosynthesis of Ag nanoparticles, Nova BiotechnologicaetChimica, 13-1, (2014).

Karnovsky and M.J., A Formaldehyde-glutaraldehyde fixative of high osmolality for use in electron microscopy, J. Cell Biol., 27, 173,(1965).

Kaviya,S.;Santhanalakshmi,J. and Viswanathan, B., Green Synthesis of silver nanoparticles using Polyalthialongifolia Leaf extract along with D-Sorbitol, Journal of nanotechnology, 1-5, (2011). 
Kim, K.; Sung,W. S.; Moon,S., Choi,J.;Kim, J. and Lee, D. .,Antifungal Effect of Silver Nanoparticles on Dermatophytes, Journal of Microbiology and Nanotechnology, 18(8), 14821484, (2008).

Klaine,S. J.; Alvarez,P. J.J.;Batley,G. E. and Fernandes, T. F., Nanomaterials in the Environment: Behavior, Fate, Bioavailability, and Effects, Envinmental Toxicology and Chemistry, 9, 1825- 1851, (2008).

Klaus-Joerger,T.;Joerger,R.; Olsson,E., and Granqvist, C.,Bacteria as workers in the living factory: metal-accumulating and potential for materials science', Trends in Biotechnology, 1, 15-20, (2001).

Lechevalier, H. A. and Solotorovsky,M., A New Genus of the Actinomycetales: Micropolyspora gen. nov., J. gen. MiHobiol., 26, 11-18, (1961).

Li, Y.;Duan, X.;Qian, Y.; Yang, L.and Liao, H.,Nanocrystalline Silver Particles: Synthesis, Agglomeration, and Sputtering Induced by Electron Beam, Journal of Colloid and Interface Science, (2), 347-349, (1999).

Mandal,D.;Bolander,M. E.;Mukhopadhyay,D.; Sarkar,G. S. and Mukherjee,P., The use of microorganisms for the formation of metal nanoparticles and their application, Applied Microbial Biotechnology, 69, 485-492, (2006).

Minaeian,S.;Shahverdi,A. R.;Nohi,A. S. and Shahverdi, H. R., Extracellular biosynthesis of silver nanoparticles by some bacteria, J. Sci. I. A. U (JSIAU), 66, 1-4, (2008).

Morones,J. R.;Elechiguerra,J. L.; Camacho,A.; Holt,K., Kouri,J. B., Ram'irez,J. T. and Yacaman, M. J.,The bactericidal effect of silver nanoparticles, Nanotechnology, 16, 2346-2353, (2005).

Narayanan,K. B. and Sakthivel, N.,Biological synthesis of metal nanoparticles by microbes, Advances in Colloid and Interface Science, (1-2), 1-13, (2010).

Nasrollahi, A.;Pourshamsian,Kh. and Mansourkiaee, P., Antifungal activity of silver nanoparticles on some of fungi, International Journal of Nano Dimension, (3): 233-239, (2011). 
Prasad,P. and Turner, M. S., An open-ended practical series involving identification of unknown foodborne bacteria using molecular techniques, The International Union of Biochemistry and Molecular Biology, 5, 384-390, (2011).

Ramezani,F.;Ramezani,M.Talebi, S., Mechanistic Aspects of Biosynthesis of Nanoparticles by Several Microbes, Nanocon, (2010).

Ranjani,A.;Gopinath,P. M.; Rajesh,K.;Dhanasekaran,D. and PriyadharsiniP.,Diversity of Silver Nanoparticle Synthesizing Actinobacteria Isolated from Marine Soil, Tamil Nadu, India, Arab J SciEng, (41), 25-32.00, (2016).

Reynolds and E.S., The use of lead citrate at high $\mathrm{pH}$ as an electron-opaque stain in electron microscopy, J. Cell. Biol., 17, 208-212, (1963).

Sarkar, A.;Saha, M. and Roy, P.,Identification and Typing of Aeromonashydrophila through 16S rDNA-PCR Fingerprinting, Aquaculture Research \& Development, 3(6), 1-4, (2012)

Sastry,M.; Ahmad,A.; Khan,M. I. and Kumar,R., Biosynthesis of metal nanoparticles using fungi and actinomycete, Current Science, 2,160-170, (2003).

Saware, K.;Sawle, B.;Salimath, B.;Jayanthi, K. and Abbaraju, V., Biosynthesis and characterization of silvernanoparticles using Ficusbenghalensis leaf extract, International Journal of Research in Engineering and Technology, (5), 867-874, (2014).

Shankar,S. Sh.;Rai, A.; Ahmad, A. and Sastry, M.,Rapid synthesis of Au, Ag, and bimetallic Au core Ag shell nanoparticles using Neem (Azadirachtaindica) leaf broth, J Colloid Interface Science, (2), 496-502, (2004).

Singh,V.;Chaudhary,D.K. and Mani, I., Molecular characterization and modeling of secondary structure of 16S rRNA from Aeromonasveronii, IJABPT, (1), 253-260, (2012).

Sondi,I. and Salopek-Sondi;B., Silver nanoparticles as antimicrobial agent: a case study on E. coli as a model for Gram-negative bacteria, Journal of Colloid and Interface Science, 275, 177182, (2004).

Song, J. Y. and Kim, B. S., Rapid biological synthesis of silver nanoparticles using plant leaf extracts, Bioprocess BiosystEng, 32, 79-84 (2009). 
Sundaram,P. A.;Augustine, R. and Kannan, M., Extracellular Biosynthesis of Iron Oxide Nanoparticles by Bacillus subtilis Strains Isolated from Rhizosphere Soil, Biotechnology and Bioprocess Engineering, 17, 835-840, (2012).

Tripathi,P.; Banerjee,G.; Gupta,M. K.;Saxena,Sh. and Ramteke, P.W., Assessment of phylogenetic affiliation using 16S rRNA gene sequence analysis for Pseudomonas aeruginosa in patients of lower respiratory tract infection, Indian J Med Res, 557-559, (2013).

Vahabi,Kh.;Mansoori,G. A. and Karimi,S., Biosynthesis of Silver Nanoparticles by Fungus TrichodermaReesei (A Route for Large-Scale Production of AgNPs), Insciences J., 1(1), 65-79; doi:10.5640/insc.010165, (2011).

Vaidyanathan, R.; Gopalram, Sh.; Kalishwaralal, K.; Deepak, V.; Pandian, S. R. K. and Gurunathan, S.,Enhanced silver nanoparticle synthesis by optimization ofnitrate reductase activity. Colloids and Surfaces B:Biointerfaces, (1), 335-341, (2010).

Vanaja,M.;Gnanajobitha,G.;Paulkumar,K.;Rajeshkumar,Sh.;Malarkodi,Ch.

and

Annadurai, G., Phytosynthesis of silver nanoparticles by Cissusquadrangularis: influence of physicochemical factors, Journal of Nanostructure in Chemistry, 3(17), 1-8, (2013).

Veerasamy,R.; Xin,T. Z.;Gunasagaran,S.; Xiang,T. F. W.; Yang,E. F. C.;Jeyakumar,N. and Dhanaraj,S. A., Biosynthesis of silver nanoparticles using mangosteen leaf extract and evaluation of their antimicrobial activities, Journal of Saudi Chemical Society, 15, 113-120, (2011).

Wang, Z.; Chen, J.; Yang, P. and Yang, W.,Biomimetic synthesis of gold nanoparticles and their aggregates using a polypeptide sequence, Appl.Organometal Chem., 21, 645-651, (2007).Waran, P. J.;Shivaraj,R. and Venckatesh, R., Green synthesis of silver nanoparticles from extract of Padinatetrastromatica leaf, Digest Journal of Nanomaterials and Biostructures, 7(3), $991-998,(2012)$.

Watts, J. L.;Shryock,Th. R.;Apley,M.; Bade,D. J.; Brown,S. D.; Gray,J. T.; Heine,H.; Hunter,R. P.;Mevius,D. J.;Papich,M. G.;Silley,P.and Zurenko, G. E., Performance standards for antimicrobial disk and dilution susceptibility tests for bacteria isolated from animals; approved standard- third edition, 8, pp.60, (2008). 


\section{تخليق جزيئات فضة نانوية من سلالة بكتيرية جديدة ودراسة تأثيرها على الفطريات الجلدية.}

أسماء المشاركين بالبحث:

$$
\text { أ.م.د. شريف موسى حسيني }
$$

أستاذ مساعد الميكروبيولوجي ـ كلية البنات للآداب و العلوم و التربية - جامعة عين شمس.

$$
\text { أ.م.د. طاهر أحمد صلاح الدين }
$$

أستاذ مساعد تكنولوجيا النانو - مدير تكنولوجيا النانو و المو اد المتقدة بالمعمل المركزي ـ مركز البحوث

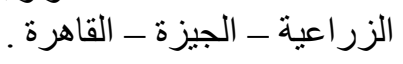

في هذا البحث تم عزل سلالة بكثريا ودر اسة مقدرتها على إنتاج جزيئات معدنية نانوية، ثم تعريف البكتريا ذات المقدرة على إنتاج جزيئات نانوية، و التي تم تسميتها (Kacillussp.)

$$
\text { أــ تم اختبار تأثير عدة عو امل على حجم جزيئات الفضة النانوية، وكانت الظروف المنلى كالاتي: }
$$

ا ـ تحضين العزلة البكتيرية لمدة 96 ساعة، و استخدام جهاز الطرد المركزي لفصل البيئة السائلة التي نمت بها العزلة

$$
\text { لاستخدامها في اختز ال حجم جزيئات الفضة. }
$$

r - النسبة الأفضل من كمية AgNO

$$
\text { ع ـ ـ درجة الحرارة المثلى لتحضين وقت التحضين مدة } 18 \text { ساعة. }
$$

$$
\text { ـ - الرقم الهيدروجيني عند } 7 .
$$

بــ تم إنتاج كمية من جزيئات الفضة النانوية بتحضين بيئة البكتريا مع AgNO3 عند الظروف المثلى التي تتناسب مع إنتاج أقل حجم.

ج-تحليل وتشخيص جزيئات الفضة النانوية باستخدام عديد من الأجهزة.

د- استخدام جزيئات الفضة النانوية الناتجة كمضاد للميكروبات الممرضة.

هـتحديد نركيز جزيئات الفضة النانوية الأقل لتتبيط نمو الخلايا الميكروبية الممرضة. 